\title{
Knowledge Level about Recommended Chickpea Production among the Beneficiaries of NFSM Programme
}

\author{
Vikram Singh $^{1}$, M. K. Chaturvedi ${ }^{1}$, Harslata $\operatorname{Sahu}^{3}$ and Rewendra Kumar Sahu ${ }^{1 *}$ \\ ${ }^{1}$ Department of Agricultural Extension, College of Agriculture, Indira Gandhi Krishi \\ Vishwavidyalaya, Raipur, Chhattisgarh, 492012, India \\ ${ }^{2}$ Rural Horticulture Extension Officer, Abhanpur, Government of Chhattisgarh, India \\ *Corresponding author
}

\section{A B S T R A C T}

\begin{tabular}{l} 
Ke y w o r d s \\
Knowledge level, \\
Chickpea \\
production, \\
National Food \\
Security Mission \\
(NFSM) \\
\hline Article Info \\
\hline $\begin{array}{l}\text { Accepted: } \\
\text { 26 April } 2020 \\
\text { Available Online: } \\
\text { 10 May } 2020\end{array}$ \\
\hline
\end{tabular}

The present study was investigated the various impact of technological interventions among the chickpea beneficiaries about NFSM programme on income and productivity in bemetara and mungeli district of Chhattisgarh state during the year 2016-17. Data was collected from beneficiaries farmers of chickpea production that were selected randomly from each selected 8 villages to make a sample size of 120 farmers of chickpea production about NFSM programme, with the help of a pre-tested interview schedule. The differences between before NFSM and after NFSM knowledge index reported highest in sowing time and method 12.56 per cent and seed treatment 12.50 per cent and lowest in land preparation 2.92 per cent and plant protection management 5.89 per cent. The differences between before and after NFSM in overall knowledge level about chickpea production in majority $(4.16 \%)$ of respondents had medium knowledge level, 3.33 per cent of high knowledge level and 0.83 per cent of low knowledge level.

\section{Introduction}

Food security and affordability top the Government's agenda as production stagnates and prices continue to be firm. The greatest challenge to agriculture in the years to come is to provide adequate food to the burgeoning population in order to combat hunger and malnutrition. We will have to feed more people with scarce water resources, recurring droughts, degrading lands and difficult access to energy. The agricultural technologies need a shift from production-oriented to profitoriented sustainable farming systems.

Accordingly, a Centrally Sponsored Scheme, National Food Security Mission (NFSM), was launched in October 2007. The Mission met with an overwhelming success and achieved the targeted additional production of rice, wheat and pulses. Chickpea (Cicer arietinum L.) is the third most important food legume 
crop in the world. Chickpea is grown in the drier areas of the country as they are best suited for its production. Chickpea producing states in India are Madhya Pradesh (29.37\%), Maharashtra (20.03\%), Andhra Pradesh (15.48\%), Rajasthan (9.73\%), Karnataka (9.63\%), Uttar Pradesh $(6.42 \%)$ \& Gujarat $(3.57 \%)$ and Chhattisgarh in ninth position (Anonymous, 2011). In Chhattisgarh, the area, production and productivity of chickpea in 2010-2011 was 2.519, 2.415 and 891, respectively.

During 2011-2012 Durg district having 1st position in cultivating area of chickpea 102.46 thousand ha with production of 110.99 thousand metric tons, Kawardha accounts 65.88 thousand ha., 58.30 thousand metric tons production, followed by Rajnandgaon 47.03 thousand ha and production 45.21thousand metric tons, respectively. But the productivity of Durg district is less than other districts. Bemetara and Mungeli district is also most chickpea growing areas.

Bemetara district in total chickpea cultivated areas 90.51 thousand ha and production 77.31 metric tons and it's a productivity is $854 \mathrm{~kg} /$ ha. Mungeli district is total chickpea cultivated areas 25.81 thousand ha and production 18.06 metric tons and it's a productivity is $700 \mathrm{~kg} / \mathrm{ha}$.

\section{Materials and Methods}

The study was conducted during the year 2016-17 in the Bemetara (Bemetara and Navagarh block) and Mungeli (Mungeli and Lormi block) districts of Chhattisgarh state. From each selected block, 2 villages were selected thus total 8 villages (Total $4 \times 2=8$ ) were selected on the basis of maximum availability of beneficiaries. From each selected village 15 beneficiaries' farmers of chickpea production, were randomly selected as respondents, in this way total $(8 \times 15) 120$ farmers were selected for collection of data. The knowledge test was composed of items called questions for constructing the knowledge tests of all the package of practices of chickpea production technology. A set of questions was developed and discussed with the disciplines of advisory committee and then finalized. Total number of questions was 9 .

A device was developed to measure the level of knowledge for farmers regarding selected technologies those recommended for chickpea crop, a teacher made scale was used with some modifications. The responses of respondents regarding knowledge were obtained into three point continuum. Nil knowledge, Partial knowledge, Full knowledge and score as $0,1,2$, respectively. The knowledge index was worked as follows:

$\mathrm{KI}=\frac{\text { Sum of knowledge score actually obtained by the respondents }}{\text { Maximum possible obtainable knowledge score by the respondents }} \mathrm{X} 100$

Further, the respondents were classified into three categories Low level of knowledge, Medium level of knowledge and High level of knowledge on the basis of following formula:

$$
\text { K. I. }=\text { Mean }(\overline{\mathrm{X}}) \pm \text { S.D. (Standard Deviation) }
$$

\section{Results and Discussion}

\section{Knowledge level about recommended chickpea production}

The data presented in before NFSM in Table 1 revealed that the respondents had full knowledge level about chickpea production. i.e. Land preparation 70.00 per cent, harvesting method 65.83 per cent, water management 60.00 per cent, balance dose of fertilizer 58.33 per cent, use of improved varieties 57.50 per cent, seed rate 55.83 per cent, sowing time and method 52.5 per cent, plant protection management 45.83 per cent 
and seed treatment 44.17 per cent. Whereas the respondents who had partial knowledge level about chickpea production i.e. plant protection 42.50 per cent, sowing time and method 35.83 per cent, seed treatment 32.5 per cent, seed rate 25.83 per cent, land preparation 21.67 per cent, balance dose of fertilizer 20.00 per cent, water management 19.17 per cent, use of improved varieties 18.33 per cent and harvesting method 10.83 per cent.

While, in case of nil knowledge groups about chickpea production were use of improved varieties 24.17 per cent, seed treatment 23.33 per cent, harvesting method 23.34 per cent, balance dose of fertilizer 21.67 per cent, water management 20.83 per cent, seed rate 18.34 per cent, sowing time and method 11.67 per cent, plant protection management 11.67 per cent and land preparation 8.33 per cent.

To find out the knowledge level of respondents about chickpea production, knowledge index was worked out. The data compiled in Table 1 depicts that respondents were having highest knowledge index reported land preparation 80.83 per cent, harvesting method 71.25 per cent, sowing time and method 70.41 per cent, water management 69.58 per cent, seed rate 68.75 per cent, balance dose of fertilizer 68.33 per cent, plant protection management 67.08 per cent, use of improved varieties 66.67 per cent and seed treatment 60.41 per cent.

The data presented in after NFSM in table 1 revealed that the respondents had full knowledge level about chickpea production i.e. land preparation 71.67 per cent, harvesting method 70.83 per cent, water management 69.17 per cent, sowing time and method 67.5 per cent, balance dose of fertilizer 65.83 per cent, use of improved varieties 60.83 per cent, seed rate 59.17 per cent, seed treatment 55.83 per cent, plant protection management 53.33 per cent. whereas the respondents who had partial knowledge level about chickpea production i.e. Plant protection management 39.17 per cent, seed rate 38.33 per cent, seed treatment 34.17 per cent, use of improved varieties 33.34 per cent, sowing time and method 30.83 per cent, balance dose of fertilizer 29.17 per cent, land preparation 24.16 per cent, water management 21.67 per cent and harvesting method 20.83 per cent.

While, in case of nil knowledge groups about chickpea production were seed treatment 10.00 per cent, water management 9.16 per cent, harvesting method 8.34 per cent, plant protection management 7.5 per cent, use of improved varieties 5.83 per cent, balance dose of fertilizer 5.00 per cent, land preparation 4.17 per cent, seed rate 2.5 per cent and sowing time and method 1.67 per cent.

To find out the knowledge level of respondents about chickpea production, knowledge index was worked out. The data compiled in Table 1 depicts that respondents were having highest knowledge index reported land preparation 83.75 per cent, sowing time and method 82.97 per cent, harvesting method 81.25 per cent, balance dose of fertilizer 80.41 per cent, water management 80.00 per cent, seed rate 78.33 per cent, use of improved varieties 77.5 per cent, plant protection management 72.97 per cent and seed treatment 72.91 per cent.

The differences between before NFSM and After NFSM knowledge index reported in highest sowing time and method 12.56 per cent, seed treatment 12.50 per cent, balance dose of fertilizer 12.08 per cent, use of improved varieties 10.83 per cent, water management 10.42 per cent, harvesting method 10.00 per cent, seed rate 9.58 per cent, plant protection management 5.89 per cent and land preparation 2.92 per cent. 
Table.1 Distribution of respondents according to their knowledge level about recommended chickpea production $(\mathrm{n}=120)$

\begin{tabular}{|c|c|c|c|c|c|c|c|c|c|c|c|c|c|c|c|c|}
\hline \multirow{3}{*}{$\begin{array}{l}\text { Sl. } \\
\text { No. }\end{array}$} & \multirow[t]{3}{*}{ Particulars } & \multicolumn{7}{|c|}{ Before NFSM } & \multicolumn{7}{|c|}{ After NFSM } & \multirow{3}{*}{$\begin{array}{c}\text { Difference } \\
\text { (KI\%) }\end{array}$} \\
\hline & & \multicolumn{2}{|c|}{ Full } & \multicolumn{2}{|c|}{ Partial } & \multicolumn{2}{|c|}{ Nil } & \multirow{2}{*}{$\begin{array}{l}\text { Index } \\
\text { (KI\%) }\end{array}$} & \multicolumn{2}{|c|}{ Full } & \multicolumn{2}{|c|}{ Partial } & \multicolumn{2}{|c|}{ Nil } & \multirow{2}{*}{$\begin{array}{l}\text { Index } \\
\text { (KI\%) }\end{array}$} & \\
\hline & & $\mathrm{F}$ & $\mathrm{P}$ & $\mathrm{F}$ & $\mathrm{P}$ & $\mathrm{F}$ & $\mathrm{P}$ & & $\mathrm{F}$ & $\mathrm{P}$ & $\mathrm{F}$ & $\mathrm{P}$ & $\mathrm{F}$ & $\mathrm{P}$ & & \\
\hline 1. & Land preparation & 84 & 70.00 & 26 & 21.67 & 10 & 8.33 & 80.83 & 86 & 71.67 & 29 & 24.16 & 5 & 4.17 & 83.75 & 2.92 \\
\hline 2. & $\begin{array}{l}\text { Use of improved } \\
\text { varieties }\end{array}$ & 69 & 57.5 & 22 & 18.33 & 29 & 24.17 & 66.67 & 73 & 60.83 & 40 & 33.34 & 7 & 5.83 & 77.5 & 10.83 \\
\hline 3. & Seed rate & 67 & 55.83 & 31 & 25.83 & 22 & 18.34 & 68.75 & 71 & 59.17 & 46 & 38.33 & 3 & 2.5 & 78.33 & 9.58 \\
\hline 4. & Seed treatment & 53 & 44.17 & 39 & 32.5 & 28 & 23.33 & 60.41 & 67 & 55.83 & 41 & 34.17 & 12 & 10.00 & 72.91 & 12.50 \\
\hline 5. & $\begin{array}{l}\text { Sowing time and } \\
\text { method }\end{array}$ & 63 & 52.5 & 43 & 35.83 & 14 & 11.67 & 70.41 & 81 & 67.5 & 37 & 30.83 & 2 & 1.67 & 82.97 & 12.56 \\
\hline 6. & $\begin{array}{l}\text { Balance dose of } \\
\text { fertilizer }\end{array}$ & 70 & 58.33 & 24 & 20.00 & 26 & 21.67 & 68.33 & 79 & 65.83 & 35 & 29.17 & 6 & 5.00 & 80.41 & 12.08 \\
\hline 7. & Water management & 72 & 60.00 & 23 & 19.17 & 25 & 20.83 & 69.58 & 83 & 69.17 & 26 & 21.67 & 11 & 9.16 & 80.00 & 10.42 \\
\hline 8. & $\begin{array}{l}\text { Plant protection } \\
\text { management }\end{array}$ & 55 & 45.83 & 51 & 42.5 & 14 & 11.67 & 67.08 & 64 & 53.33 & 47 & 39.17 & 9 & 7.5 & 72.97 & 5.89 \\
\hline 9. & Harvesting method & 79 & 65.83 & 13 & 10.83 & 28 & 23.34 & 71.25 & 85 & 70.83 & 25 & 20.83 & 10 & 8.34 & 81.25 & 10.00 \\
\hline
\end{tabular}

$\mathrm{F}=$ Frequency, $\mathrm{P}=$ Percentage, $\mathrm{F}=$ Full, $\mathrm{P}=$ Partial, N=Nil, KI =Knowledge index, *Data are based on multiple responses

Table.2 Distribution of respondents according to their overall knowledge level about recommended chickpea production

\begin{tabular}{|c|c|c|c|c|c|c|c|c|}
\hline \multirow[t]{2}{*}{ Sl. No. } & \multirow[t]{2}{*}{ Knowledge Level } & \multicolumn{2}{|c|}{ Before } & \multirow[t]{2}{*}{ Knowledge Level } & \multicolumn{2}{|c|}{ After } & \multicolumn{2}{|c|}{ Difference } \\
\hline & & $\mathrm{F}$ & $\mathrm{P}$ & & $\mathrm{F}$ & $\mathrm{P}$ & $\mathrm{F}$ & $\mathrm{P}$ \\
\hline 1. & Low (<10 score) & 24 & 20.00 & Low $(<12$ score $)$ & 25 & 20.83 & 1 & 0.83 \\
\hline 2. & Medium (11-15 score) & 88 & 73.33 & Medium(13-16score) & 83 & 69.17 & 5 & 4.16 \\
\hline 3. & High (>15 score) & 8 & 6.67 & High(>16 score) & 12 & 10.00 & 4 & 3.33 \\
\hline
\end{tabular}




\section{Overall knowledge level about recommended chickpea production}

The findings regarding knowledge about chickpea production practices are presented in Table 2 shown that before NFSM majority $(73.33 \%)$ of the respondents had medium level knowledge about chickpea production practices, 20.00 per cent of the respondents had low level of knowledge and only 6.67 per cent of the respondents had high level of knowledge about chickpea production practices.

Whereas the respondents who had after NFSM majority $(69.17 \%)$ per cent of the respondents had medium level knowledge about chickpea production, 20.83 per cent of the respondents had low level of knowledge and 10.00 per cent of the respondents had high level of knowledge about chickpea production. The differences between before and after NFSM in overall knowledge level about chickpea production in majority $(4.16 \%)$ of respondents had medium knowledge level, 3.33 per cent of high knowledge level and 0.83 per cent of low knowledge level.

The findings of study in before NFSM the respondents had full knowledge level about chickpea production in land preparation, that respondents were having highest knowledge index reported land preparation. The regarding after NFSM revealed that the respondents had full knowledge level about chickpea production in land preparation was having highest knowledge index reported land preparation.

Followed by the difference between before and After NFSM knowledge index reported in highest sowing time and method. The findings regarding overall level of knowledge about chickpea production before NFSM had medium level and after NFSM had medium level. The differences between before and after NFSM in overall level of knowledge about chickpea production in majority of respondents had medium level of knowledge.

\section{Acknowledgements}

The Authors are indebted to the Department of Agricultural Extension, Indira Gandhi Krishi Vishwavidhayalya, Chhattisgarh for financial support.

\section{References}

Anonymous, 2012. Project coordinator's report, All India coordinated research project on chickpea.

Anonymous, 2015-2016. www.agridept.cg.gov.in/agriculture.

Dayananad Patel, G. P. 1985. A study on knowledge level and training needs of sericulturists. M.Sc. (Agri.) thesis (Un pub.) Univ. Agric. Sci. Bangalore.

Gour, S., Mandal, M.K. and Singh, R. 2015. Assessing knowledge of tribal farmers regarding scientific animal husbandry practices. Indian Res. J. Ext. Edu., 15(2): 92.

Kirar, B.S. and Mehta, B.K. 2009. Extent of knowledge of tribal farmers about rice production technology Indian. Res. J. Ext. Edu., 9(1): 33.

Manjunatha, A.V. and Kumar, P. 2015. Impact of national food security mission (NFSM) on input use, production, yield and income in Karnataka. Agricultural Development and Rural Transformation Centre Institute for Social and Economic Change Bangalore-560 072.

Narain, S., Singh, S.K. and Singh, L. 2014. Impact of national food security mission-pulse on chickpea productivity in Hamirpur district of Uttar Pradesh. Indian Res. J. Ext. Edu. 14(3): 24-27.

Rajput, A.S., Choubey, N.K., Kolhe, S.S. and Umate, S.M. 2003. Impact of irrigation 
schedules and weed management practices on yield and economics of late sown chickpea in Vertisols. International Chickpea Conference, C. G., India. Jan, 20-22: 301-304.

Roy, R. 2014. Impact of national food security mission (NFSM) on input use, production, productivity and income in Uttar Pradesh. Agro-Economic Research Centre University of Allahabad -211002: 80-85.

Savapandit, R. and Kakaty, G. 2015. Impact of national food security mission (NFSM) on input use, production, productivity and income in Assam. Agro-Economic Research Centre for North East India Assam Agricultural University Jorhat-785013, Assam.

Sekhar, C.S.C. and Bhatt, Y. 2012.
Possibilities and constraints in pulses production in India and impact of national food security mission. (Final Report) Institute of Economic Growth University of Delhi Enclave Delhi 110007, 7: 150.

Shah, D. 2011. Possibilities and constraints in increasing pulse production in Maharashtra and the impact of national food security mission on pulses. Gokhle Institute of Politics and Economics (Deemed to be University) Pune - 411 004: 71-76.

Sharma, P., Singh, G.P. and Jha, S.K. 2013. Impact of training programme on knowledge and adoption of preservation technologies among farm women: A Comparative Study Indian. Res. J. Ext. Edu., 13(1): 97.

\section{How to cite this article:}

Vikram Singh, M. K. Chaturvedi, Harslata Sahu and Rewendra Kumar Sahu. 2020. Knowledge Level about Recommended Chickpea Production among the Beneficiaries of NFSM Programme. Int.J.Curr.Microbiol.App.Sci. 9(05): 3313-3318. doi: https://doi.org/10.20546/ijcmas.2020.905.394 